
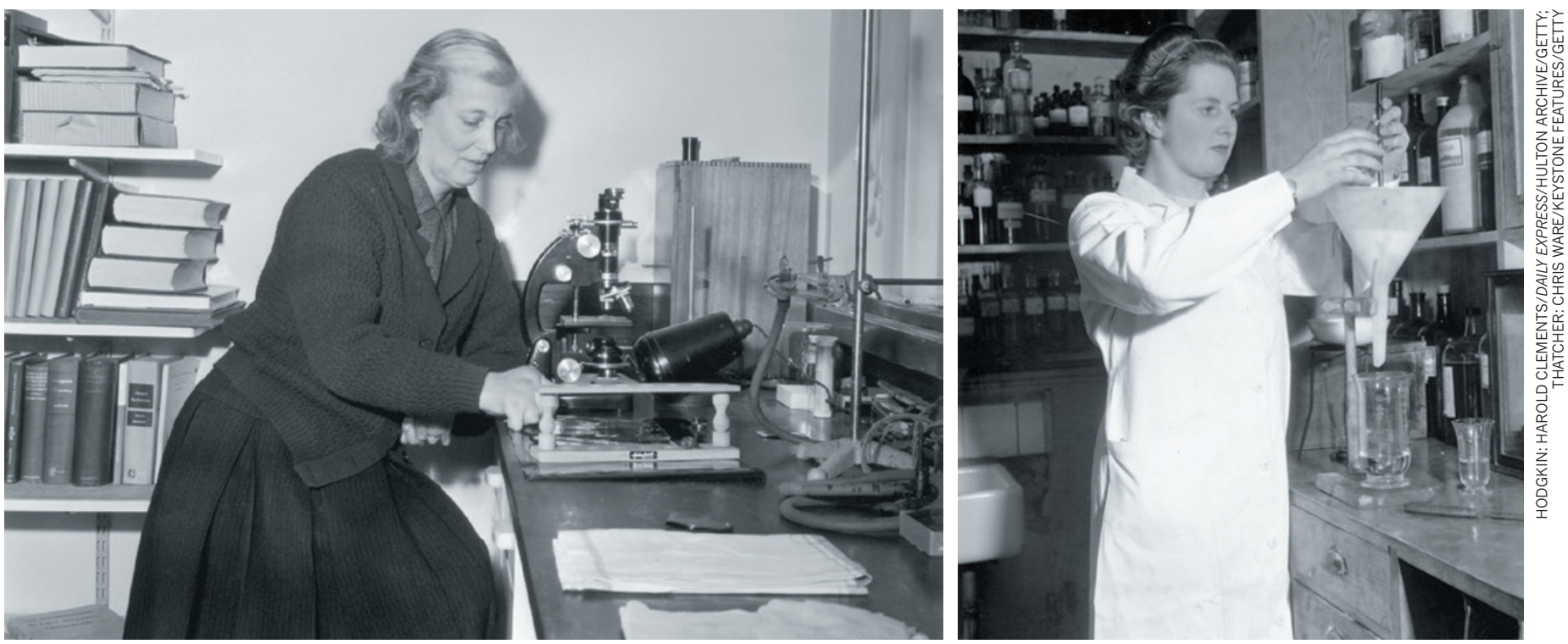

Dorothy Hodgkin (left) supervised future British Prime Minister Margaret Thatcher (Roberts at the time) in her undergraduate chemistry studies at Oxford.

\title{
POLITICS
}

\section{When Hodgkin met Thatcher}

\section{Jessa Gamble on a radio play about the Nobel laureate and the UK prime minister.}

$\mathrm{F}$ ifty years ago this month, crystallographer Dorothy Crowfoot Hodgkin became the only British woman to win a Nobel prize in science. To mark the occasion, Adam Ganz's radio play The Chemistry Between Them imagines an overlooked chapter of Hodgkin's storied life: the period during the 1940s when she mentored a singular undergraduate in her lab at the University of Oxford's Somerville College. That undergraduate was the only scientist, and the only woman, to become prime minister of Britain - Margaret Thatcher.

Ganz's play centres on a 1983 meeting between Hodgkin and Thatcher at the prime minister's country home, Chequers, intercut with scenes in the lab. Ganz contrasts the two women's politics, and traces the evolution of Thatcher's character under Hodgkin's tutelage. He drew on Georgina Ferry's Dorothy Hodgkin: A Life (Granta, 1998), Hodgkin's own writings and interviews with some who knew her, such as the chemist Judith Howard.

The Chemistry Between Them opens with a nervous Margaret Roberts, as she then was, newly arrived at Oxford from a life above her father's shop. Hodgkin, 15 years her senior, begins to exert a subtle influence, introducing cosmopolitan and feminist ideas into the younger woman's conservative Methodist mind. In their scientific discourse on structural stability and the antibiotic gramicidin B, Hodgkin nudges Roberts to abandon her black-and-white mindset in favour of more nuanced thinking.
Then we jump for- The Chemistry ward 40 years to the Between Them height of the cold war. ADAM GANZ Hodgkin is president BBC Radio 4: $\begin{array}{ll}\text { of the Pugwash confer- } & \text { Broadcast on } \\ 20 \text { August } 2014 .\end{array}$ ences on science and peace, trying to sway Thatcher, now prime minister, towards nuclear disarmament. Their politics were polarized. Hodgkin was awarded the Soviet Union's Lenin Peace Prize for furthering understanding between East and West, and was banned from entering the United States - except by a Central Intelligence Agency waiver - because her husband was a member of the UK Communist Party. Like many scientists of the 1930s and 1940s, she saw communism as the only system likely to fund science with an eye to the long view. Basic research seemed too easily dismissed as inefficient by free marketeers - an attitude that had its heyday during Thatcher's tenure, despite her scientific training.

A puzzling flaw in the play is the assumption that there was any friendship between the two. Thatcher kept a picture of the crystallographer at 10 Downing Street in London, but the sentiment was not so fondly returned, according to family members. As an academic and a lobbyist, Hodgkin's visits to Chequers were explicitly political, and she was openly critical of Thatcher.

Ganz has explored the interplay between science, politics and morality before. His 2010 work Nuclear Reactions used transcripts from Farm Hall, a bugged English country house where captured German nuclear physicists were interned, and their conversations recorded, after the Second World War (see A. Finkbeiner Nature 503, 466-467 (2013) for another take on these events).

Very different dynamics, politics and ethics pervade The Chemistry Between Them. Beyond its portrayal of two towering women, it depicts the radicalism of scientists of Hodgkin's generation, and their decency and morality. Crystallographer J. D. Bernal, Hodgkin's PhD supervisor, serves as a standin for the unconventional thinkers with whom she mixed, from the philosopher and anti-nuclear activist Bertrand Russell to the political theorist Isaiah Berlin. Matter-offact discussions of contraception and marital infidelity mark the group as radical for its time.

Through her willingness to question consensus, Hodgkin became an exceptionally creative and powerful scientist. This play does not enhance what we know of her life, nor does the dialogue ring true for those who knew her. Where it does succeed is in showing that for her and many others, science was an integral part of moral and political life.

Jessa Gamble is a writer based in Yellowknife, Canada, and author of The Siesta and the Midnight Sun. Her grandmother was Dorothy Hodgkin's first cousin.

e-mail:jessa_sinclair@yahoo.com 